\title{
Analgesic, Antidiarrheal and CNS-depressant Activities of Flemingia macrophylla (Willd.)
}

\section{Asheka Rahman', Mohammad Mahmudul Hasan', Mohammad Abdullah Taher ${ }^{3}$ and Tanvir Muslim ${ }^{1}$}

\author{
${ }^{1}$ Department of Chemistry, University of Dhaka, Dhaka, Bangladesh \\ ${ }^{2}$ Department of Chemistry, Jashore University of Science and Technology, Jashore, Bangladesh \\ ${ }^{3}$ Department of Pharmacy, State University of Bangladesh, Dhanmondi, Dhaka, Bangladesh
}

(Received: June 27, 2020; Accepted: July 15, 2020; Published (web): July 25, 2020)

\begin{abstract}
Plants are the priceless sources of bioactive natural compounds. Medicinal plants have been used since time immemorial in both developing and developed countries. Flemingia macrophylla (Willd.) is widely used as a hereditary medicines. The current study was designed to observe the analgesic, antidiarrheal and CNS depressant activities of methanol extract of the leaves of $F$. macrophylla (MEFM) and its petroleum ether (PEFM), dichloromethane (DFM), chloroform (CFM) and aqueous (AFM) fractions. The analgesic activities was assessed by acetic acid induced writhing method at doses 200- and 400$\mathrm{mg} / \mathrm{kg}$ body weight. The CNS-depressant effect was assayed by phenobarbitone sodium-induced sleeping time test. The anti-diarrheal activity of the extract was evaluated using castor oil-induced diarrhea in mice. The crude extract displayed significant peripheral analgesic activity at both test doses with 56.72- to 59.70-\% inhibition of writhing responses, respectively. In CNS-depressant test, the extract revealed its activity in a dose dependent manner. In screening for antidiarrheal activity, the extract exhibited 20.83 and $41.67 \%$ inhibition of defecation at 200- and $400-\mathrm{mg} / \mathrm{kg}$ bw, respectively whereas the standard loperamide $(50 \mathrm{mg} / \mathrm{kg}$ bw) displayed $70.83 \%$ inhibition of defecation.
\end{abstract}

Key words: Flemingia macrophylla, Analgesic, Antidiarrheal, CNS-depressant.

\section{Introduction}

Plants have been the fundamental resources of many noble medicines in the world and ready to provide any kind of new remedies (Samuelsson, 2004). Various types of bioactive natural compounds are attained from medicinal herbs and they serve as raw materials for noble drug discovery (Ramawat et al., 2009). The interconnection between man and drugs for disease is proportional. The use of drugs and dietary supplements accessed from plants have raised in recent years. Scientists such as pharmacologists, microbiologists, botanists, and phytochemists are working with phytochemicals for developing medicines for various diseases. This study was therefore based on electronic database (Google Scholar, SciFinder, PubMed, etc.)

Flemingia macrophylla is a 1-4 meter long woody, perennial, deep rooting and tussock farming shrub, which belongs to the family Fabaceae. It is the third largest flowering plant. The roots of this plant have been used in folk medicines for the treatment of trauma, arthritis, rheumatism and influenza. Previous studies with $F$. macrophylla with have reported the neuroprotective (Shiao et al., 2005), analgesic and anti-inflammatory activities (Ko et al., 2010). It was also found to be effective in the treatment of osteoporosis (Ho et al., 2011). The decoction of root of $F$. macrophylla are used as an external application

Corresponding author: Tanvir Muslim; E-mail: tmuslim@gmail.com

DOI: https://doi.org/10.3329/bpj.v23i1.48334 
to ulcers and swellings, mainly of the neck (Kirtikar et al., 1993).

Taking into account of its medicinal value to the traditional healers, the leaves of $F$. macrophylla were subjected to different bioassays to determine its analgesic, anti-diarrheal and CNS-depressant activities with the goal to execute the pharmacological basis for its folkloric use in different disorders.

\section{Materials and Methods}

Collection of plant material: The leaves of $F$. macrophylla (Willd.) were collected from Jahangirnagar University Campus, Savar, Bangladesh and identified by an expert of Bangladesh National Herbarium, Dhaka, where a voucher specimen has also been retained.

Drying and grinding: The collected plant materials were cleaned with water and subjected to shed-drying for one week followed by oven drying below $40^{\circ} \mathrm{C}$ and then ground to a coarse powder with a grinding machine (Wuhu motor factory, China). Finally, the powder material was stored in an airtight container and kept in a dark, cool and dry place until further processing.

Cold extraction: The powered plant material (500 gm) was taken in a clean glass container and soaked in $2500 \mathrm{ml}$ of methanol for 15 days with occasional shaking and stirring. The mixture was then filtered by Whatman filter paper number 1 . The filtrate was concentrated using a rotary evaporator at $40^{\circ} \mathrm{C}$ under reduced pressure. About $5 \mathrm{gm}$ of the concentrated extract of $F$. macrophylla was subjected to solvent-solvent partitioning following the modified Kupchan partitioning protocol (Van Wagenen et al., 1993) into petroleum ether (PEFM), dichloromethane (DFM), chloroform (CFM) and aqueous (AFM) soluble fractions. Then the crude extract and its Kupchan fractions were separately evaluated for biological activities.
Drugs and reagents: Methanol, Tween-80, loperamide (Square Pharmaceuticals Ltd.), normal saline (Opsonin Pharmaceuticals Ltd.) and phenobarbitone-Na (Gonoshasthaya Pharmaceuticals Ltd.), acetyl salicylic acid (Aspirin) (Essential Drugs Company Ltd.) and castor oil were collected as indicated. All other chemicals and reagents were of analytical grade.

Experimental animals: Swiss-albino mice of either sex (18-22 g) were obtained from the Animal Resources Branch of the International Centre for Diarrheal Diseases and Research, Bangladesh (icddr,b). They were harbored in standard polypropylene cages at a constant temperature of 24 $\pm 2^{\circ} \mathrm{C}$ and relative humidity $60-70 \%$ with $12 \mathrm{hrs}$ light-dark cycle for 1 week at least before the experiment. They were fed with food and water ad libitum. Animals used in this study were housed and handled in accordance with the NIH Guide for the Care and Use of Laboratory Animals. The placebo groups were administered orally with $0.1 \mathrm{ml} / 10 \mathrm{gm}$ bw saline. All tests were conducted under the guidelines of the International Association for the Study of Pain (Young et al., 2005).

Acetic acid-induced writhing test: The analgesic activity of the sample was carried out in mice by using acetic acid-induced writhing method (Biswas et al., 2009; Hossain et al., 2016). Mice were divided into 4 groups of 5 mice in each group. The control group received $1 \%$ Tween-80 in normal saline (10 $\mathrm{ml} / \mathrm{kg} \mathrm{bw}$ ), the standard group received Aspirin (50 $\mathrm{mg} / \mathrm{kg} \mathrm{bw}$ ) and the experimental groups received crude extract of two different doses of 200 and 400 $\mathrm{mg} / \mathrm{kg}$ bw. After 30 minutes, each mouse was injected with $1 \%$ acetic acid at a dose of $10 \mathrm{ml} / \mathrm{kg}$ bw. The number of muscular contractions was counted over a period of $5 \mathrm{~min}$ after acetic acid injection. The total number of writhing was observed and counted for $10 \mathrm{~min}$ and the percentage of inhibition was calculated by using the following formula:

\footnotetext{
Mean number of writhing (control) - Mean number of writhing (drug)

Percentage inhibition of writing $=\frac{\text { Mean number of writhing (control) }}{}$
} 
Evaluation of antidiarrheal activity: To evaluate castor oil-induced antidiarrheal activity of the extract, the experimental mice were also divided into four groups: two test groups, control and standard consisting of 5 mice in each group. The negative and positive control groups received Tween-80 (1\% in water) and the standard drug, loperamide $(50 \mathrm{mg} / \mathrm{kg}$ bw) whereas the test groups of mice received the extractives at 200 and $400 \mathrm{mg} / \mathrm{kg}$ bw. After 60 minutes, $0.5 \mathrm{ml}$ of castor oil was administered to each mouse of all groups through the oral route. In order to count the number of faces all animals were then kept separately in transparent cage having white blotting paper. The blotting paper was changed in every hour and it was observed for a period of 5 hours. The mean number of feces (dry and wet diarrheal droppings) was determined and compared with the negative control group (Rahman et al., 2010; Hasan et al., 2017; Islam et al., 2013). By using the following formula the percent inhibition of defecation was calculated:

Percent inhibition $=\left(D_{0}-D_{1} / D_{0}\right) \times 100 \%$

Where, $\mathrm{D}_{0}$ is the number of defecation of the control group, and $D_{1}$ is the number of defecation of the test or standard group.

CNS-depressant activity: For assaying the CNSdepressant activity, the crude methanol extract of $F$. macrophylla was subjected to phenobarbitone-Na induced sleeping time test (Rahman et al., 2015). Here, the test groups were orally administered with test samples prepared in normal saline water and Tween-80 at doses of 200 and $400 \mathrm{mg} / \mathrm{kg}$ bw, while the positive control group was treated with diazepam $(1 \mathrm{mg} / \mathrm{kg} \mathrm{bw})$ and the negative control group with normal saline water containing $1 \%$ Tween-80. After $30 \mathrm{~min}$, phenobarbitone- $\mathrm{Na}(40 \mathrm{mg} / \mathrm{kg}$ bw) was administered intraperitoneally to each mouse to induce sleep. The animals were observed for the latent period for time of onset of sleep (i.e., time between phenobarbitone-Na injection and loss of righting reflex) and duration of sleep (i.e., time between the loss and recovery of righting reflex).

\section{Results and Discussion}

Acetic acid-induced writhing test: The results of the test showed that MEFA exhibit significant $(\mathrm{p}<$ 0.01 ) inhibition of writhing reflex by 56.72 and $59.70 \%$ at the doses of 200 and $400 \mathrm{mg} / \mathrm{kg}$, respectively while the standard (Aspirin, $50 \mathrm{mg} / \mathrm{kg}$ bw) drug was found to inhibit the writing response by $80.60 \%$ (Table 1). The result was statistically evaluated and the t-test and $\mathrm{p}$ values were determined. The test materials exhibited significant peripheral analgesic activity at both the doses while the methanolic extract at $400 \mathrm{mg} / \mathrm{kg}$ dose exhibited maximum inhibition of writhing $59.70 \%$. Statistical evaluation of the data confirmed that the crude extract showed significant peripheral analgesic activity at both 200 and $400 \mathrm{mg} / \mathrm{kg}$ doses with percent inhibition of writhing within the range of 56.72 to $59.70 \%$, respectively.

Table 1. Analgesic activity of methanol extract of $F$. macrophylla leaves in acetic acid-induced pain in mice.

\begin{tabular}{lccc}
\hline $\begin{array}{l}\text { Treatment } \\
(\mathrm{n}=5)\end{array}$ & $\begin{array}{c}\text { Dose } \\
(\mathrm{mg} / \mathrm{kg})\end{array}$ & $\begin{array}{c}\text { No of } \\
\text { writhes }\end{array}$ & $\begin{array}{c}\% \\
\text { Inhibition }\end{array}$ \\
\hline Control & $1 \%$ Tween-80 & 22.33 & --- \\
Aspirin & 50 & 4.33 & 80.60 \\
MEFA & 200 & 9.67 & 56.72 \\
MEFA & 400 & 9.00 & 59.70 \\
\hline
\end{tabular}

Evaluation of antidiarrheal activity: In the castor oil-induced diarrhea, administration of MEFA significantly $(\mathrm{p}<0.01)$ decreased the total number of faeces in mice after at the doses of 200 and 400 $\mathrm{mg} / \mathrm{kg}$ bw as well as delayed the onset of diarrhea in a dose dependent manner. The methanolic extract of leaves of $F$. macrophylla exhibited statistically significant anti-diarrheal activity with a $20.83 \%$ and $41.67 \%$ reduction of diarrhea at dose of 200- and $400-\mathrm{mg} / \mathrm{kg}$ bw compared to the standard drug, loperamide (70.83\% inhibition) (Table 2). 
Table 2. Effects of methanol extract of $\boldsymbol{F}$. macrophylla leaves on castor oil-induced diarrhea in mice.

\begin{tabular}{lcc}
\hline Group & $\begin{array}{c}\text { Number of } \\
\text { stools after } 4 \\
\text { hrs (mean) }\end{array}$ & $\begin{array}{c}\text { Inhibition of } \\
\text { defecation } \\
(\%)\end{array}$ \\
\hline $\begin{array}{l}\text { Control (1\% } \\
\text { Tween-80 in water) }\end{array}$ & 8.00 & --- \\
$\begin{array}{l}\text { Standard } \\
\text { (Loperamide 50 }\end{array}$ & 2.33 & 70.83 \\
mg/kg bw) \\
MEFA 200 mg/kg bw \\
MEFA 400 mg/kg bw
\end{tabular}

Evaluation of CNS-depressant activity: The methanol extract of leaves of $F$. macrophylla slightly increased the phenobarbitone sodium-induced sleeping time in a dose dependent manner (Table 3). In the control group of mice, the time of onset of sleep was 150.33 min whereas in experimental group it was $62.33 \mathrm{~min}$ and $110.67 \mathrm{~min}$ at 400 and 200 $\mathrm{mg} / \mathrm{kg}$ body weight, respectively. The total sleeping time was about $177.67 \mathrm{~min}$ and $129.33 \mathrm{~min}$ at the doses of 400 and $200 \mathrm{mg} / \mathrm{kg}$ body weight, respectively while in control group it was $89.67 \mathrm{~min}$. This experimental finding from the study showed that the methanol extract of leaves of $F$. macrophylla have mild CNS-depressant activity in mice.

Table 3. CNS-depressant activity of crude extract of $\boldsymbol{F}$. macrophylla in Swiss Albino mice.

\begin{tabular}{lcc}
\hline Test groups & $\begin{array}{c}\text { Time of onset of } \\
\text { sleep (min.) }\end{array}$ & $\begin{array}{c}\text { Total sleeping } \\
\text { time (min) }\end{array}$ \\
\hline Control & 150.33 & 89.67 \\
Diazepam & 58.33 & 181.67 \\
$(1 \mathrm{mg} / \mathrm{kg}$ b.w. $)$ & & \\
MEFA & 110.67 & 129.33 \\
$(200 \mathrm{mg} / \mathrm{kg} \mathrm{b.w.)}$ & & \\
MEFA & 62.33 & 177.67 \\
$(400 \mathrm{mg} / \mathrm{kg}$ b.w. $)$ & & \\
\hline
\end{tabular}

\section{Conclusion}

The current study with the rude methanolic extract of F. macrophylla demonstrated significant analgesic and antidiarrheal activities but mild CNSdepressant activities However, further studies are necessary to isolate the bioactive compounds and explain the probable mechanisms related to these bioactivities.

\section{Acknowledgments}

The authors are thankful to the Department of Pharmacy, State University of Bangladesh for providing laboratory facilities and instrumental support. Special thanks to the authority of International Centre for Diarrheal Disease and Research, Banglades (icddr,b) for providing experimental mice.

\section{References}

Biswas, M., Biswas, K., Ghosh, A.K. and Haldar, P.K. 2009. A Pentacyclic triterpenoid possessing analgesic activity for the fruit of Dregea volubilis. Pharmacog. Mag. 5, 90-92.

Hasan, M.M., Hossain, A., Shamim, M.A. and Rahman, M.M, 2017. Phytochemical and pharmacological evaluation of ethanolic extract of Lepisanthes rubiginosa L. leaves. BMC Complem. Altern. Med. 17, 496.

Ho, H.Y.; Wu, J.B. and Lin, W.C. 2011. Flemingia macrophylla extract ameliorates experimental osteoporosis in ovariectomized rats. Evid. Based Complement. Alternat. Med. doi:10.1093/ecam/ nep179.

Hossain, A., Islam, T., Saifuzzaman, Saeed, M.A.S., Islam, M.K., Murshid, G.M.M. and Rahman, M.M. 2016. Bioactivity of Boehmeria macrophylla (Urticaceae) leaf extract. Orien. Pharm. Exp. Med. 16, 233--241.

Islam, M.K., Mahmud, I., Saha, S., Sarker, A.B., Mondal, H., Monjur-Al-Hossain, A.S.M. and Anisuzzman, M. 2013. Preliminary pharmacological evaluation of Alocasia indica Schott tuber. J. Integr. Med. 11, 343351.

Kirtikar, K.R. and Basu, B.D. 1993. Indian Medicinal Plants, Allahabad Lalit Mohan Basu, India. pp. 814815.

Ko, Y.J., Lu, T.C., Kitanaka, S., Liu, C.Y., Wu, J.B., Kuo, C.L., Cheng, H.Y., Lin, Y.C. and Peng, W.H. 2010. Analgesic and anti-inflammatory activities of the aqueous extracts from three Flemingia species. Am. J. Chin. Med. 38, 625-638.

Rahman, M.S., Jahan, N. Rahman, S.M.A. and Rashid, M.A. 2015. Analgesic and antidepressant activities of Brassica rapa subspecies chinensis (L.) Hanelt on Swiss Albino mice model. Bangladesh Med. Res. Counc. Bull. 41, 114-120. 
Rahman, A., Riyanto, S., Yuniarti, N., Saputra, W.R., Utami, R. and Mulatsih, W. 2010. Antioxidant activity, total phenolic and total flavonoid of extracts and fractions of red fruit (Pandanus conoideus Lam). Int. Food Res. J. 17, 97-106.

Ramawat, K.G., Das, S. and Mathur, M. 2009. The chemical diversity of bioactive molecules and therapeutic potential of medicinal plants, in: Ramawat, K.G. (Eds.), Herbal drugs: ethnomedicine to modern medicine. Berlin: Springer. pp. 7-32.

Samuelsson, G. 2004. Drugs of Natural Origin: A Text of Pharmacognosy, 4th revised ed. Swedish Pharmaceutical Press, Stockholm, Sweden. pp. 417429.
Shiao, Y.J., Wang, C.N., Wang, W.Y. and Lin, Y.L. 2010. Neuroprotective flavonoids from Flemingia macrophylla. Planta Med. 71, 835-840.

Van Wagenen, B.C., Larsen, R., Cardellina, J. H., Randazzo, D., Lidert, Z.C. and Swithenbank, C. 1993. Ulosantoin, a potent insecticide from the sponge Ulosa ruetzleri. J. Org. Chem. 58, 335-337.

Young, H.Y., Luo, Y.L., Cheng, H.Y., Hsieh, W.C., Liao, J.C. and Peng, W.H. 2005. Analgesic and antiinflammatory activities of [6]-gingerol. $J$. Ethnopharmacol. 96, 207-210. 